\title{
GEOCHEMICAL SIGNATURE OF THE BRASILIANO-AGE PLUTONISM IN THE SERIDÓ BELT, NORTHEASTERN BORBOREMA PROVINCE (NE BRAZIL)
}

\section{MARCOS ANTONIO LEITE DO NASCIMENTO, ALEX FRANCISCO ANTUNES, ANTONIO CARLOS GALINDO, EMANUEL FERRAZ JARDIM DE SÁ AND ZORANO SÉRGIO DE SOUZA}

\begin{abstract}
The Seridó Belt (Borborema Province, NE Brazil) displays a strong imprint of the late Neoproterozoic Brasiliano orogenic cycle. The most important megascopic structures in the Seridó Belt are strike-slip shear zones, coeval with the emplacement of several granitoid bodies. The paper is based on 217 chemical analyses of the granitoid plutons grouped into five different geochemical suites (Shos - Shoshonitic, PKCAlk - Porphyritic K-Calc-Alkaline, EqKCAlk-Equigranular K-Calc-Alkaline, Alk-Alkaline and ChAlk - Charnockitic Alkaline). They are distinguished by petrographic and textural features, as well as Harker's and geochemical discriminant diagrams. The Shos is easily distinguished

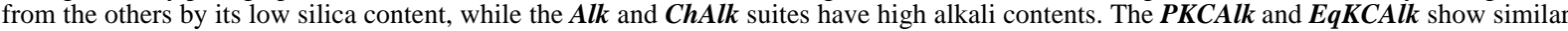
geochemical behaviour; but they can be separated mainly by petrographic and textural aspects. Field relationships and geochemical affinities suggested that the Shos, PKCAlk, EqKCAlk and $\boldsymbol{A l k}$ are approximately coeval, syntectonic plutons, whereas the $\boldsymbol{C h A l k}$ is interpreted as lateto post-tectonic as regards to the Brasiliano orogeny.
\end{abstract}

Keywords: Seridó Belt, Brasiliano orogeny, plutonism, geochemistry, discriminant diagrams

INTRODUCTION One of the most characteristic features of the Seridó Belt is the huge plutonic activity at the end of the Brasiliano Cycle $(550 \pm 50 \mathrm{Ma})$. This plutonism is represented by a large number of batholiths, stocks and dikes, widely distributed in the Seridó Bel (Fig. 1) and displaying different petrographic and geochemical characteristics.

Different classification proposals were elaborated at a regional basis, encompassing all the Borborema Province. The classical paper of Almeida et al. (1967) subdivided the granitoid rocks, with respect to the Brasiliano orogeny, into four groups: the syntectonic Itaporanga and Conceição types, and the late-tectonic Catingueira and Itapetim types. Geochemical classifications of Brasiliano granitoids were put forward by Sial (1986) and Ferreira et al. (1998), among others, who emphasized the magmatic affinities of these rocks.

In the Seridó Belt, Jardim de Sá et al. (1981) called attention to the emplacement of the granitoid rocks related to different orogenic episodes, and named the Brasiliano plutons as the $G_{3}$ granitoids (porphyritic or equigranular, besides late leucogranites and basic-tointermediate rocks). Jardim de Sá (1994) characterized the "basic-tointermediate", "porphyritic" and "leucogranite" suites, besides synand post-tectonic alkaline suites, later on described by Galindo (1993), Hollanda (1998), Nascimento (1998), Jardim de Sá et al. (1999) and Nascimento (2000).

The present paper aims to synthesize the chemical data presently available in the region (217 analyses) and to propose a uniform systematic nomenclature for the Brasiliano-age plutonism in the Seridó Belt.

\section{GEOCHEMICAL CHARACTERISTICS OF THE PLUTONIC} SUITES The database used for the classification proposal was selected from a number of the chemical analyses available in the literature (all references used are listed in Table 1), dealing with the several Brasiliano-age plutons. The data were treated, excluding those with anomalous values. Samples of doubtful provenance were not considered.

This classification was based mainly upon the chemical characteristics of each sample group, as well as on their petrographic aspects and modal compositions. The nomenclature of each group or suite reflects to its magmatic affinity, identified by discriminant diagrams. In this work, it was possible to characterize five plutonic suites in the Seridó Belt, named as follows: Shoshonitic (Shos), Porphyritic K-Calc-Alkaline (PKCAlk); Equigranular K-Calc-Alkaline (EqKCAlk); Alkaline (Alk) and Charnockitic Alkaline (ChAlk). All these suites are represented in figure 1 .

The Shoshonitic Suite (Shos) It occurs as isolated plutons (e.g. São João do Sabugi and Quixaba) or closely associated to the PKCAlk Suite (e.g. São José de Espinharas, Totoró and Cardoso). It comprises rocks of varied composition, ranging from gabbro/diorite to quartz monzonite, with equigranular or inequigranular fine- to medium-grained texture (coarser in the gabbroic terms, sometimes with plagioclase phenocrysts). The latter types also exhibit augite, diopside and/or hypersthene phenocrystals, which may be transformed to amphibole. In the most differentiated types (diorites and quartz monzonites), hastingsitic to $\mathrm{Fe}$-edenitic hornblende is the dominant mafic phase, besides biotite. The commonest accessory minerals are sphene, opaque minerals (magnetite and/or ilmenite), zircon and apatite.

The $\mathrm{SiO}_{2}$ contents in the Shos Suite vary between 48 and $60 \%$, corresponding to the least differentiated plutonic rocks studied. The $\mathrm{K}_{2} \mathrm{O} / \mathrm{Na}_{2} \mathrm{O}$ ratio ranges from 0,3 to 1,6 (Table 2). Harker's diagrams ( $\mathrm{SiO}_{2}$ as the differentiation index), show negative correlation for $\mathrm{Fe}_{2} \mathrm{O}_{3}$ and $\mathrm{MgO}$, and positive for $\mathrm{K}_{2} \mathrm{O}$ (Fig. 2). $\mathrm{Rb}, \mathrm{Ba}$ and $\mathrm{Zr}$ have typically incompatible behavior, whereas $\mathrm{Sr}$ seems to be a compatible element for $\mathrm{SiO}_{2}$ values greater than $55 \%$ wt (Fig. 2). The REE are weakly to moderately fractionated $\left(\mathrm{La}_{\mathrm{N}} / \mathrm{Yb}_{\mathrm{N}}=11-70\right)$, with positive or negative Eu anomalies (Table 2).

The Porphyritic K-Calc-Alkaline Suite (PKCAlk) It is widely distributed in the Seridó Belt, being represented by isolated batholiths or plutons associated to the other suites, especially the Shos. The PKCAlk Suite comprises porphyritic coarse-grained rocks with high proportions of $\mathrm{K}$-feldspar phenocrystals. It is the dominant facies in the majority of the granitoid massifs, like the ones of Acari, Monte das Gameleiras, São José de Espinharas, Serra do Lima-Caraúbas, Barcelona and Totoró (Fig. 1). Medium-grained varieties, in which the Kfeldspar phenocrystals are smaller than $2 \mathrm{~cm}$ in length, may also occur. The PKCAlk plutons have mainly a monzogranitic composition, although granodioritic and quartz monzonitic varieties may be found. The mafic phases are biotite, hastingsitic to Fe-edenitic hornblende, while sphene, epidote, allanite, zircon, apatite and magnetite are the main accessory minerals.

The PKCAlk Suite exhibits alkali enrichment $\left(\mathrm{K}_{2} \mathrm{O}+\mathrm{Na}_{2} \mathrm{O}^{37 \%} \%\right)$, and has the greatest $\mathrm{K}_{2} \mathrm{O} / \mathrm{Na}_{2} \mathrm{O}$ (Table 2). In Harker's diagrams, $\mathrm{Fe}_{2} \mathrm{O}_{3+}$ and $\mathrm{MgO}$ are negatively correlated against $\mathrm{SiO}_{2}$ (Fig. 2). Both $\mathrm{Sr}$ and $\mathrm{Ba}$ have compatible behavior, whereas $\mathrm{Rb}$ appears to be an incompatible element (Fig. 2). Concerning the REE, they are weakly to moderately fractionated, with $(\mathrm{La} / \mathrm{Yb})_{N}$ ratios between 20 and 80 , and always show moderately to strongly negative Eu anomalies (Table 2).

The Equigranular K-Calc-Alkaline Suite (EqKCAlk) Rocks of the EqKCAlk Suite occur as sheets, dikes and sills, isolated bodies (e.g. Taipu, Dona Inês and Picuí plutons - Fig. 1) or associated to the PKCAlk Suite (e.g. Acari and São José de Espinharas plutons). This suite is composed principally by fine- to medium-grained equigranular monzogranites. The main accessory mineral is biotite $( \pm$ amphibole), besides subordinated amounts of sphene, epidote, opaque minerals, apatite, zircon, allanite and tourmaline. Some facies of the Picuí (Silva 1993) and Dona Inês plutons (McMurry et al. 1987) contain garnet.

The EqKCAlk Suite shows narrow $\mathrm{SiO}_{2}$ variation (68-76\%) and high $\mathrm{K}_{2} \mathrm{O} / \mathrm{Na}_{2} \mathrm{O}$ ratio $(1,1-2,3)$. Harker's diagrams (Fig. 2) present negative correlation for $\mathrm{Fe}_{2} \mathrm{O}_{3}, \mathrm{MgO}$ and $\mathrm{Na}_{2} \mathrm{O}$. Sr, $\mathrm{Ba}$ and $\mathrm{Zr}$ show compatible behavior, and $\mathrm{Rb}^{3 \mathrm{t}}$ is an incompatible element (Fig. 2).

Departamento de Geologia, UFRN, Caixa Postal 1639, CEP 59.078-970, Natal/RN. - E-mails: marcos@geologia.ufrn.br, alex@geologia.ufrn.br, galindo@geologia.ufrn.br, emanuel@geologia, ufrn.br, zorano@geologia.ufrn.br 


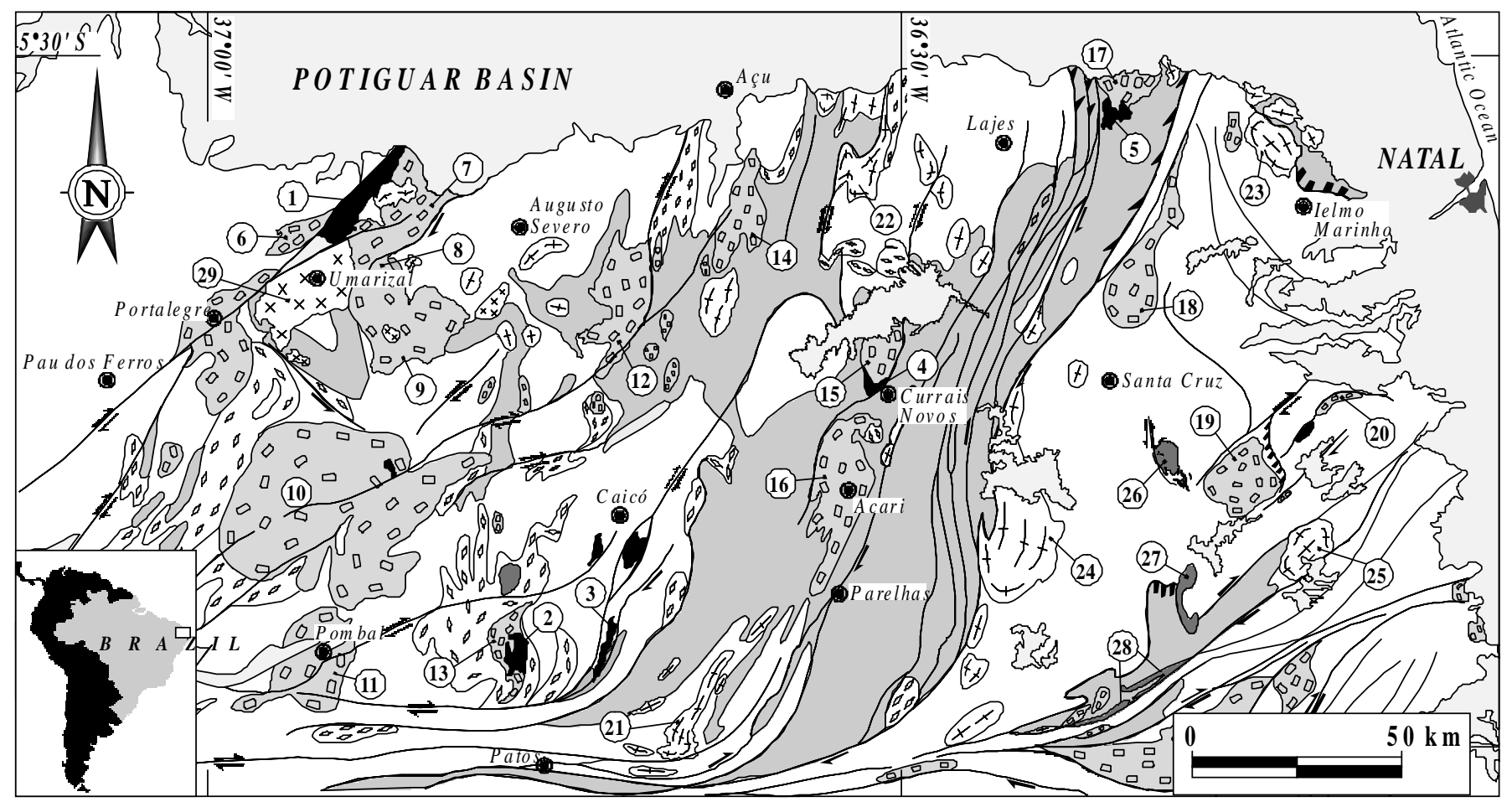

BRASILIANO-A GE PLUTONS OF THE SERIDÓ BELT

\begin{tabular}{|c|c|c|c|c|}
\hline Shoshonitic Suite & & Porphyritic K-Calc-Alkaline & Suite & $\begin{array}{c}\text { Equigranular K-Calc- } \\
\text { Alkaline Suite }\end{array}$ \\
\hline \begin{tabular}{l|l} 
(1) & Quixaba \\
\end{tabular} & (6) Prado & (11) Pombal & (16) Acari & (21) Santa Luzia \\
\hline (2) São José de Espinharas & (7) Caraúbas & (12) Serra João do Vale & $\begin{array}{ll}17 & \text { Cardoso } \\
\end{array}$ & \begin{tabular}{|l|l|}
22 & Angicos \\
\end{tabular} \\
\hline \begin{tabular}{|l|l} 
(3) & São João do Sabugi \\
\end{tabular} & $\begin{array}{ll}\text { (8) } & \text { Tourão } \\
\end{array}$ & (13) São José de Espinharas & \begin{tabular}{|l|l|}
18 & Barcelona \\
\end{tabular} & $\begin{array}{ll}23 & \text { Taipu } \\
\end{array}$ \\
\hline (4) Totoró & (9) Serra do Lima & (14) São Rafael & (19) Monte das Gameleiras & (24) Picuí \\
\hline \begin{tabular}{|l|l|l|}
5 & Cardoso \\
\end{tabular} & (10) Catolé do Rocha & (15) Totoró & \begin{tabular}{|l|l|}
20 & Serrinha \\
\end{tabular} & $\begin{array}{ll}255) & \text { Dona Inês } \\
\end{array}$ \\
\hline
\end{tabular}

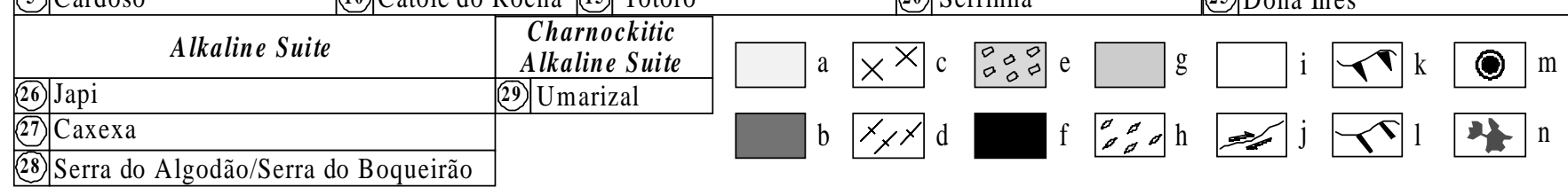

Figure 1 - Geological map of the Seridó Belt, emphasizing the Brasiliano magmatic suites (modified after Jardim de Sá 1994). a - Meso to Cenozoic covers; $\boldsymbol{b}$ - Brasiliano alkaline plutons; $\boldsymbol{c}$ - Brasiliano charnockitic alkaline plutons; $\boldsymbol{d}$ - Brasiliano equigranular $\mathrm{K}$-calc-alkaline plutons; $\boldsymbol{e}$ - Brasiliano porphyritic K-calc-alkaline plutons; $\boldsymbol{f}$ - Brasiliano shoshonitic plutons; $\boldsymbol{g}$ - Proterozoic metasupracrustals; $\boldsymbol{h}$ - Paleoproterozoic granitoid plutons; $\boldsymbol{i}$ - Archaean to Paleoproterozoic gneissic-migmatitic basement; $\boldsymbol{j}$ - Brasiliano transcurrent shear zones; $\boldsymbol{k}$ - Brasiliano contractional-transpressive shear zones; $\boldsymbol{l}$ - Brasiliano extensional shear zones; $\boldsymbol{m}$ - Town; $\boldsymbol{n}$ - capital city of state.
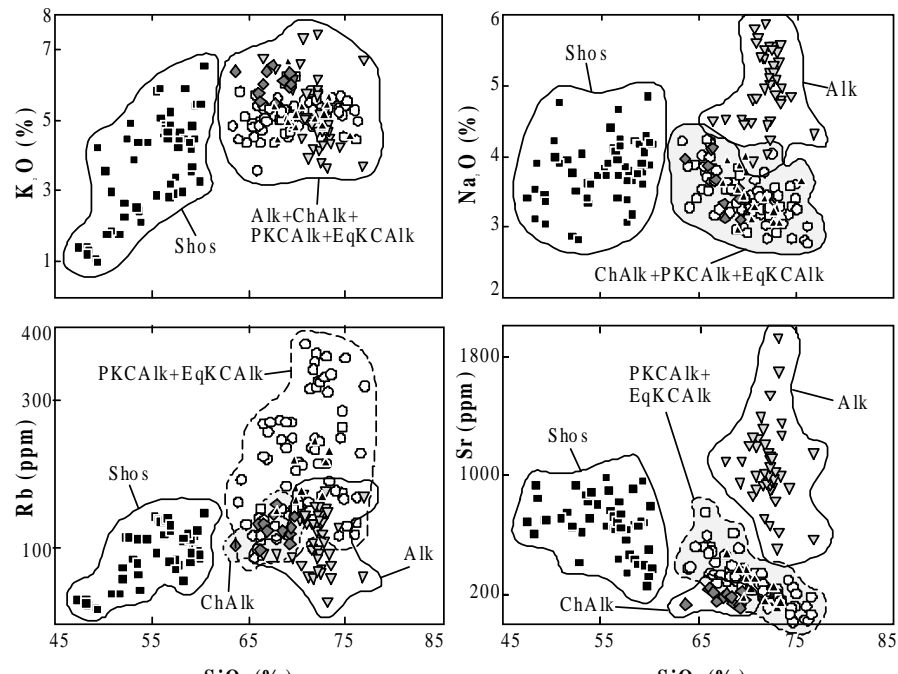

$\mathrm{SiO}(\%)$
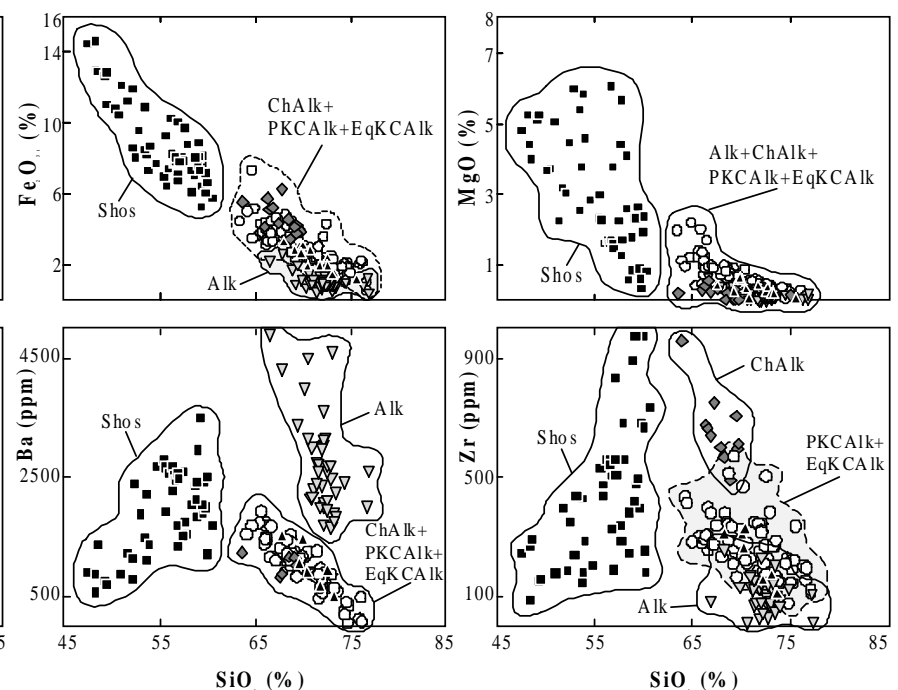

Figure 2 - Harker's diagrams for the Brasiliano-age magmatic suites in the Serido Belt, using $\mathrm{SiO}_{2}$ as the differentiation index. Legend: $\mathbf{\square}$ Shos = Shoshonitic, $O P K C A l k=$ Porphyritic K-Calc-Alkaline, $\mathbf{\Delta}$ EqKCAlk =Equigranular K-Calc-Alkaline, $\nabla$ Alk $=$ Alkaline, $\diamond$ ChAlk $=$ Charnockitic Alkaline. 
Table 1 - Bibliographical sources used to characterize the Brasiliano magmatic suites in the Serido Belt, with a total of 217 chemical analyses (amounts between parentheses).

\begin{tabular}{|l|l|l|}
\hline \multicolumn{1}{|c|}{ SuITES (NUMBER OF ANAL YSES) } & \multicolumn{1}{|c|}{ STUdiED Plutons } & \multicolumn{1}{c|}{ SourCE } \\
\hline Shoshonitic (57) & São João do Sabugi; Totoró; Acari; & Jardim de Sá (1994), Galindo (1993). \\
\hline Porphyritic K-Calc-Alkaline (87) & $\begin{array}{l}\text { Acari; Totoró; Barcelona; Monte } \\
\text { das Gameleiras; Patu-Caraúbas. }\end{array}$ & $\begin{array}{l}\text { Galindo (1982, 1993), Jardim de Sá } \\
\text { (1994). }\end{array}$ \\
\hline Equigranular K-Calc-Alkaline (17) & $\begin{array}{l}\text { Dona Inês; Picuí; Acari; Monte das } \\
\text { Gameleiras. }\end{array}$ & $\begin{array}{l}\text { McMurry } \text { et al. (1987), Silva (1993), } \\
\text { Galindo (1982), Jardim de Sá (1994). }\end{array}$ \\
\hline Alkaline (45) & $\begin{array}{l}\text { Caxexa; Japi; Serra do Algodão; } \\
\text { Serra do Boqueirão. }\end{array}$ & $\begin{array}{l}\text { R.S.C. Nascimento (1998), Hollanda } \\
\text { (1998), M.A.L. Nascimento (2000). }\end{array}$ \\
\hline Charnockitic Alkaline (11) & Umarizal. & Galindo (1993). \\
\hline
\end{tabular}

Table 2 - Comparative chemical parameters of the Brasiliano magmatic suites in the Serido Belt. Opx = Orthopyroxene; Cpx = Clinopyroxene; Amph = Amphibole; Bio = Biotite; Garn = Garnet $;$ Sph = Sphene $;$ Fay = Fayalite. Eu $E u^{*}=$ europium anomaly $=E u_{N} /\left[\left(S m_{N}+G d_{N}\right) / 2\right]$. REE normalized according to the chondritic values of Evensen et al. (1978).

\begin{tabular}{|l|c|c|c|c|c|}
\hline \multicolumn{1}{|c|}{ Suites } & Shoshonitic & $\begin{array}{c}\text { Porphyritic } \\
\text { K-Calk- } \\
\text { Alkaline } \\
\text { (PKCAlk) }\end{array}$ & $\begin{array}{c}\text { Equigranular } \\
\text { K-Calk- } \\
\text { Alkaline } \\
\text { (EqKCAlk) }\end{array}$ & Alkaline & $\begin{array}{c}\text { Charnockitic } \\
\text { Alkaline } \\
\text { (ChAlk) }\end{array}$ \\
\hline $\mathrm{SiO}_{2}$ & $47,5-60,4$ & $61,8-76,6$ & $67,7-75,5$ & $66,6-76,9$ & $63,6-69,4$ \\
$\mathrm{~K}_{2} \mathrm{O} / \mathrm{Na}_{2} \mathrm{O}$ & $0,30-1,57$ & $0,85-2,14$ & $1,13-2,25$ & $0,69-1,50$ & $1,36-1,96$ \\
$\mathrm{~K}_{2} \mathrm{O}+\mathrm{Na}_{2} \mathrm{O}$ & $4,35-8,98$ & $7,24-9,49$ & $8,11-9,66$ & $8,03-11,23$ & $8,62-10,36$ \\
$\mathrm{R} / \mathrm{Sr}$ & $0,03-0,40$ & $0,12-2,40$ & $0,32-1,81$ & $0,01-0,30$ & $0,41-1,13$ \\
$\mathrm{Mafic}$ & $\mathrm{Opx}, \mathrm{Cpx}$, & $\mathrm{Bio}$, & Bio, & Cpx, Garn, & Fay, Opx, Cpx \\
phases & $\mathrm{Amph}, \mathrm{Bio}$ & $\mathrm{Amph}, \mathrm{Sph}$ & Garn, Amph & Sph, Amph & Amph, Bio \\
& & & & & \\
$\mathrm{A} / \mathrm{CNK}$ & $0,55-1,04$ & $0,83-1,10$ & $0,95-1,12$ & $0,86-1,09$ & $0,88-1,02$ \\
$\mathrm{~A} / \mathrm{NK}$ & $1,18-2,52$ & $1,15-1,51$ & $1,19-1,41$ & $0,89-1,19$ & $1,13-1,27$ \\
$(\mathrm{La} / \mathrm{Yb})_{\mathrm{N}}$ & $11-70$ & $20-80$ & $15-135$ & $4-17$ & $12-62$ \\
$\mathrm{Eu} / \mathrm{Eu} *$ & $0,64-1,20$ & $0,33-0,77$ & $0,37-0,72$ & $1,46-2,91$ & $0,52-1,21$ \\
$\mathrm{Zr}(\mathrm{ppm})$ & $155-1000$ & $143-397$ & $109-330$ & $11-230$ & $337-962$ \\
\hline
\end{tabular}

Moderately to strongly negative Eu anomalies (similar to the ones of PKCAlk Suite) and largest range on the $(\mathrm{La} / \mathrm{Yb})_{N}$ ratios (15-135) are remarkable features (Table 2). It is difficult to distinguish it from PKCAlk Suite, although the last one has some samples richer in $\mathrm{MgO}$, $\mathrm{Rb}, \mathrm{Sr}$ and $\mathrm{Zr}$.

The Alkaline Suite (Alk) This suite was recognized in the São José de Campestre Massif, the eastern domain of the Seridó Belt, comprising the Caxexa, Japi, Serra do Algodão and Serra do Boqueirão plutons (Fig. 1). The Alk Suite is composed by equigranular, fine-grained alkali-feldspar granites, with subordinate quartz-alkalifeldspar syenite. Aegirine-augite and hedenbergite are the main mafic minerals, although andradite-rich garnet may be observed in the Caxexa, Serra do Algodão and Serra do Boqueirão plutons. The plagioclase is pure albite $\left(\mathrm{An}_{0-5}\right)$ or slightly enriched in $\mathrm{Ca}\left(\mathrm{An}_{5-9}\right)$ in the garnet-bearing rocks. The accessory minerals are sphene, apatite, zircon, allanite and magnetite.

The Alk Suite shows strong enrichment in alkalis, the greatest $\mathrm{Na}_{2} \mathrm{O}, \mathrm{Sr}$ and $\mathrm{Ba}$ contents and the lowest $\mathrm{MgO}(<0,5 \%)$ and $\mathrm{Rb} / \mathrm{Sr}$ ratios (Table 2; Fig. 2). Figure 2 demonstrates that $\mathrm{Sr}$ and $\mathrm{Ba}$ are the most compatible elements. These rocks exhibit the least fractionated REE patterns, with $(\mathrm{La} / \mathrm{Yb})$ ratios between 4 and 17 , and a strongly positive Eu anomaly (Table 2).

The Charnockitic Alkaline Suite (ChAlk) Rocks with alkaline affinity also occur in the extreme NW corner of the Serido Belt, being represented by the Umarizal Pluton, which defines the ChAlk Suite. They are composed of medium-grained to inequigranular rocks, with quartz mangeritic to charnockitic composition. Their mafic assemblage may include fayalite $\left(\mathrm{Fa}_{98}-\mathrm{Fo}_{2}\right)$ or Fe-hypersthene, hedenbergite, Fe-edenitic hornblende and biotite, besides subordinated zircon, apatite, allanite, magnetite and ilmenite.
The ChAlk Suite shows high $\mathrm{K}_{2} \mathrm{O} / \mathrm{Na}_{2} \mathrm{O}$ and $\mathrm{Rb} / \mathrm{Sr}$ ratios and $\mathrm{Zr}$ contents (Table 2). $\mathrm{Na}_{2} \mathrm{O}, \mathrm{Fe}_{2} \mathrm{O}_{3}, \mathrm{MgO}, \mathrm{Ba}, \mathrm{Zr}$ and $\mathrm{Sr}$ are negatively correlated against $\mathrm{SiO}_{2}^{2}$ (Fig. 2). The REE are fractionated in the same range as found in the PKCAlk and EqKCAlk suites, but the ChAlk is distinguished for having either negative or positive Eu anomalies (Table 2).

\section{GEOCHEMICAL AFFINITIES OF THE PLUTONIC SUITES}

The plutonic suites were plotted in some discriminant diagrams for distinguishing their major geochemical affinities (Fig. 3). With respect to the Shand's index, the Shos Suite is metaluminous, and the others ones are meta to peraluminous (Fig. 3a), all of them with $\mathrm{A} / \mathrm{CNK}$ ratio less than 1.2 (Table 2). The suites are transitional between the subalkaline and alkaline series, except for the one (Alk) which clearly presents an alkaline affinity (Figs. 3b, c, d). The ChAlk Suite shows geochemical characteristics transitional between the Alk and PKCAlk ones, approximately following the monzonitic differentiation trend (Figs. 3b, c).

\section{DISCUSSION AND CONCLUDING REMARKS}

The

chemical and petrographic comparisons of the Brasiliano-age plutonic rocks allowed the individualization of five main suites: Shoshonitic, Porphyritic K-Calc-Alkaline, Equigranular K-Calc-Alkaline, Alkaline and Charnockitic Alkaline. Shos and Alk suites are easily separated from the others. The ChAlk Suite can be distinguished from the others in some diagrams. The major difficulty stands in the distinction between $P K C A l k$ and $E q K C A l k$ suites, once they are chemically very similar. However, petrographic and field aspects should be used to distinguish themselves.

A number of studies in different areas point to a complex geochemical and relative chronology of the Brasiliano-age magmatic suites in the Seridó Belt. Even though representing different parental magmas and sources, frequent magma mingling and mixing features are displayed between the Shos and PKCAlk suites, which are broadly contemporaneous across the region. The Alk Suite displays magmatic and tectonic fabrics of syntectonic intrusions, whereas the ChAlk Suite clearly crosscuts the Brasiliano-age regional structures and does not reveal any evidence of ductile deformation, which suggest its late- to post-tectonic emplacement.

According to Jardim de Sá (1994), the outstanding structural control of the plutons by the Brasiliano shear zone network suggests that these structures were deeply rooted, tapping different sources at mantle and lower to middle crustal depths. The sub-alkaline affinity commonly displayed by these igneous suites may be ultimately related to an anomalous and old, enriched lithospheric mantle source directly involved in the petrogenesis of the Shos and the alkaline suites. This mantle signature was transferred to the lower crust probably during the Paleoproterozoic tectonomagmatic evolution, and thus explains the sub-alkaline affinity of the crustal-derived Brasiliano granitoids like PKCAlk and EqKCAlk.

Acknowledgements To CNPq for the financial support through scholarships and grants, and to two anonymous referees of RBG for the review of the manuscript. 

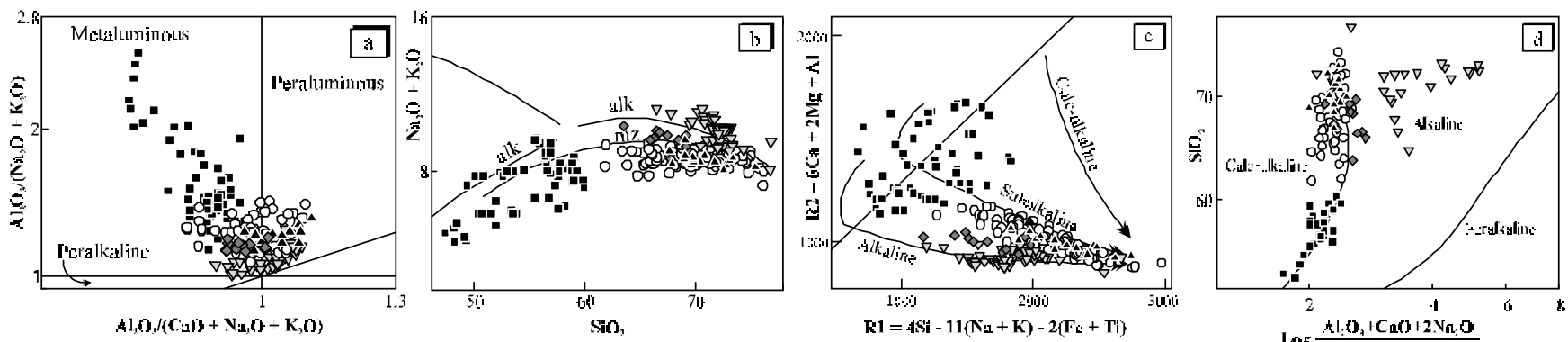

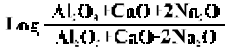

Figure 3 - Geochemical diagrams for the Brasiliano-age magmatic suites in the Seridó Belt. (a) Shand's index (Maniar and Piccoli 1989). (b) Total alkalis vs. $\mathrm{SiO}_{2}$ with the monzonitic ( $\mathrm{mz}$ ) and alkaline (alk) trends represented (Lameyre 1987). (c) R1-R2 cationic plot (De La Roche et al. 1980). (d) Alkalinity index (Wright 1969). Symbols as in figure 2.

\section{References}

Almeida F.F.M., Leonardos Jr. O.H., Valença J. 1967. Review on granitic rocks of northeast South America. IUGS/UNESCO. Symp., Recife, 41p.

De La Roche H., Leterrier J., Granclaude P., Marchal M. 1980. A classification of volcanic and plutonic rocks using R1-R2 diagram and major element analyses. Its relationship with current nomenclature. Chem. Geol., 29:183-210.

Evensen N.H., Hamilton P.J., O'Nions R.K. 1978. Rare earth abundances in chondritic meteorite. Geochim. Cosmochim. Acta. 42:1199-1212.

Ferreira V.P., Sial A.N., Jardim de Sá E.F. 1998. Geochemical and isotopic signature of Proterozoic granitoids in terranes of the Borborema structural province, NE Brazil. J. South Amer. Earth Sci., 11:439-455.

Galindo A.C. 1982. Estudo petrológico do corpo granítico de Monte das Gameleiras (RN$P B$. Centro de Tecnologia, UFPE, Recife, Ms. Thesis, 99p.

Galindo A.C. 1993. Petrologia dos granitóides brasilianos da região de CaraúbasUmarizal, oeste do Rio Grande do Norte. Centro de Geociências, UFPA, Belém, $\mathrm{PhD}$. Thesis, $370 \mathrm{p}$

Hollanda M.H.B.M. 1998. Mecanismos de alojamentos de magmas granitóides: exemplo do Plúton de Japi $(R N)$. Prog. Pós-Grad. em Geodinâmica e Geofísica, UFRN, Natal, MSc. Thesis, 126p.

Jardim de Sá E.F. 1994. A Faixa Seridó (Província Borborema, NE do Brasil) e o seu sig nificado geodinâmico na cadeia Brasiliana/Pan-Africana. Instituto de Geociências, UnB, Brasília, PhD Thesis, 803p.

Jardim de Sá E.F., Legrand J.M., McReath I. 1981. "Estratigrafia" de rochas granitóides na região do Seridó (RN-PB) com base em critérios estruturais. Rev. Bras. Geoc., 11:50-57.
Jardim de Sá E.F., Trindade R.I.F., Hollanda M.H.B.M., Araújo J.M.M., Galindo A.C., Amaro V.E., Souza Z.S., Vigneresse J.L., Lardeaux J.M. 1999. Brasiliano syntectonic alkaline granites emplaced in a strike slip/extensional setting (Eastern Seridó Belt, NE Brazil). An. Acad. Bras. Ciênc., 71:17-27.

Lameyre J. 1987. Granites and evolution of the crust. Rev. Bras. Geoc., 17:349-359.

Maniar P.D. \& Piccoli P.M. 1989. Tectonic discrimination of granitoids. Geol. Soc. Amer Bull., 101:635-643.

McMurry J., Long L.E., Sial A.N. 1987. Evolution of a heterogeneous, continentally derived granite: Dona Inês pluton, NE Brazil. J. Geol., 95:107-117.

Nascimento M A.L 2000. Petrologia do magmatismo tardi-Brasiliano no Maciço São José de Campestre (RN/PB), com ênfase ao Plúton Caxexa. Prog. de Pós-Grad. Geodinâmica e Geofísica, UFRN, Natal, MSc Thesis, 142p.

Nascimento R.S.C. 1998. Petrologia dos granitóides brasilianos associados à Zona de Cisalhamento Remígio-Pocinhos (PB). Prog. de Pós-Grad. Geodinâmica e Geofísica, UFRN, Natal, MSc Thesis, 133p.

Sial A.N. 1986. Granitic types in northeast Brazil: current knowledge. Rev. Bras. Geoc. 16:54-72.

Silva M.R.R. 1993. Petrographical and geochemical investigations of pegmatites in the Borborema pegmatitic province of NE Brazil. Fak. Geowissenschaffen, LudwigMaximilians-Universitat. PhD Thesis, 305p.

Wright J.B. 1969. A simple alkalinity ratio and its application to questions of non-orogenic granite genesis. Geol. Mag., 106:370-384.

Contribution IGC-178 Received March 9, 2000 Accepted for publication May 1, 2000 